\title{
Power in the Global Refugee Regime: Understanding Expressions and Experiences of Power in Global and Local Contexts
}

\author{
JAMES MILNER AND KRYSTYNA WOJNAROWICZ
}

\begin{abstract}
Since the late 1980s, scholars have highlighted the role of diverse conceptualizations of power in explaining the functioning of the global refugee regime. Part of this literature has examined the functioning of power in global contexts, while another part has explored expressions and experiences of power in local contexts. While these approaches illustrate how power may be expressed and experienced in the diverse contexts of the regime, can we conceptualize power in a way that engages with the functioning of the refugee regime in both global and local contexts? Can a more disaggregated understanding of power, sensitive to form and context of expression, open new areas of enquiry into the functioning of the regime and help explain its ability and inability to fulfill its core mandate of protection and solutions for refugees? In response, this article draws on the literature on power in global governance to propose a heuristic framework for understanding power and influence in the diverse context of the global refugee regime. It argues that various forms of power co-exist within the regime, and that further research could usefully examine the manifestations and implications of these forms of power through the making and implementation of global refugee policy.
\end{abstract}

\section{Résumé}

Depuis la fin des années 8o, les universitaires soulignent le rôle des diverses conceptions du pouvoir dans le fonctionnement du régime international des réfugiés. Une partie de la littérature examine le fonctionnement $d u$ pouvoir dans des contextes internationaux, une autre les formes et les pratiques de pouvoir dans des contextes locaux. Tandis que ces approches illustrent comment le pouvoir peut s'exprimer et être vécu dans divers contextes du régime des réfugiés, pouvons-nous conceptualiser le pouvoir d'une manière qui fasse un lien avec le fonctionnement du régime des réfugiés dans les contextes locaux et internationaux? Est-ce qu'une approche plus fragmentée du pouvoir, sensible à la forme et au contexte de son expression, ouvrirait de nouveaux champs de recherche sur le fonctionnement du régime des réfugiés et contribuerait à expliquer sa capacité et son incapacité à remplir son mandat fondamental de protection des réfugiés et de mise à disposition de solutions les concernant? Pour répondre à ces questions, cet article puise dans la littérature traitant du pouvoir dans la gouvernance mondiale afin de proposer un cadre heuristique pour comprendre le pouvoir et l'influence dans les divers contextes $d u$ régime international des réfugiés. Il défend lidée que des formes variées de pouvoir coexistent à l'intérieur du régime, et que des travaux de recherche supplémentaires pourraient examiner de manière pertinente les manifestations et les conséquences de ces formes de pouvoir dans la conception et la mise en cuvre de la politique internationale des réfugiés.

\section{Introduction}

T $\mathrm{n}$ the aftermath of the Second World War, states formalized a global refugee regime. ${ }^{1}$ This regime was created to perform two primary functions: to help ensure the protection of refugees and to find a solution to their plight. More than sixty years later, however, the regime has 
not predictably fulfilled these two functions. In an effort to understand the limitations of the global refugee regime, scholarship in the field of refugee studies over the past two decades has engaged with issues of politics and power. A focus of this work has been to understand the functioning of the regime at a global level and the factors that condition the ability of the regime to fulfill its core functions across contexts. ${ }^{2}$ There has likewise been a sustained interest in the role that politics and interests play in constraining the regime, 3 or, more recently, in expanding the scope and functioning of the regime. ${ }^{4}$ Likewise, a substantial literature has examined expressions of power in local contexts, with emphasis on the relationships between power, governance, and control, along with an understanding of how these expressions of power are experienced, resisted, and contested by a range of actors, including refugees. 5

Indeed, reflections on power in the global refugee regime are far from new. Yet while this literature has made significant contributions to our understanding of the diverse forms of power within the global refugee regime and the consequences of power for the functioning of the regime itself, the study of power within the global refugee regime remains fragmented, based on conceptualizations of power and the context within which power is expressed and experienced. In fact, there has been limited sustained dialogue between approaches that examine the functioning of power within the institutions of the global refugee regime, primarily at the global level, and expressions and experiences of power in local contexts. Given the central role that power is seen to play in the functioning of the regime in various contexts, and given that these forms and expressions of power may function and be experienced differently in various contexts or "scales" of the regime, ${ }^{6}$ fostering dialogue between understandings of power could usefully open new areas of enquiry into the functioning of the global refugee regime and contribute to a more comprehensive understanding of the regime's ability or inability to fulfill its core mandate of protection and solutions for refugees.

To this end, this article asks, What are the forms of power present in the global refugee regime? How is power expressed and experienced in diverse contexts? How can understandings of these diverse expressions of power be brought into conversation to encourage a more comprehensive understanding of the role of power in the functioning of the regime? In response, this article presents a heuristic framework for understanding power in the global refugee regime, which is intended to serve both as a common point of reference for contributions to this special issue and as a basis for future research. It draws from the broader literature on power and its functioning in the context of global governance to argue that power can be observed in the global refugee regime largely in accordance with the taxonomy proposed by Barnett and Duvall.7 This taxonomy argues that power exists and can be expressed in four forms: compulsory, institutional, structural, and productive. In considering these four forms of power, it is argued that our understanding of expressions of power needs to include a discussion of how power is experienced and the forms of resistance and contestation that are present in diverse contexts. On the basis of this understanding, the article argues that the functioning of power in the global refugee regime can be usefully observed and understood in the day-to-day practice of the regime, particularly in the making and implementation of global refugee policy. ${ }^{8}$

\section{Power and the Global Refugee Regime}

In the early 1980 os, Krasner characterized a regime as "sets of implicit or explicit principles, norms, rules, and decisionmaking procedures around which actors' expectations converge in a given area of international relations," such as trade or the environment. ${ }^{9}$ More recently, Betts has argued that regimes, in essence, have "two core elements: norms and international organizations." 10 In this way, the study of regimes assumes that regimes are created in response to the perception of a shared issue or concern, that norms are developed to provide a template for common agreed behaviour in responding to this shared concern, and that institutions are developed to facilitate cooperation in this area, both through providing a decision-making mechanisms where new and unforeseen issues may be addressed and by developing expertise and knowledge on how the norms of the regime can be upheld and applied in different contexts.

These core elements of a global regime are arguably present in what emerged as the "global refugee regime" in the aftermath of the Second World War. ${ }^{11}$ The first element of the regime are the norms detailed in the 1951 Convention. These norms include a definition of who may benefit from refugee status, and the rights and obligations to be afforded to such individuals. At the same time, states created UNHCR as a specialized UN agency whose mandate is twofold. Article 1 of UNHCR 1950 Statute details that UNHCR, "acting under the authority of the General Assembly, shall assume the function of providing international protection ... and of seeking permanent solutions for the problem of refugees." Despite significant growth in the size of UNHCR and the scope of its activities since its inception, these two responsibilities arguably remain the core responsibilities of the global refugee regime.

But why do states create regimes, such as the global refugee regime? While some realist international relations scholars have largely dismissed the impact of regimes, ${ }^{12}$ others have argued that states act through global regimes because it helps them "achieve their ends," either because they are able 
to determine the terms and outcomes of regimes, or because they are able to gain material and other benefits from participation. ${ }^{13}$ Neo-liberal approaches tend to view regimes as important opportunities to overcome collective action failure and facilitate international cooperation to shared problems, ${ }^{14}$ while constructivist approaches identify the potential for regimes, generally, and international organizations, specifically, to become independent actors in the international system. ${ }^{15}$ Others have convincingly challenged early assumptions that regimes are "benevolent, voluntary, cooperative, and thus legitimate associations,"16 arguing instead that regimes are forums of contestation where actors seek to influence the functioning of the regime, notwithstanding the objectives of the regime and the norms it was supposedly created to propagate.

These perspectives are all arguably relevant to the study and functioning of the global refugee regime. For example, realists might argue that the United States has established itself as the hegemon within the global refugee regime, given the scale of its financial and other contributions to UNHCR, and that it understands this support of-and influence within - the regime to be an extension of its interests and foreign policy. ${ }^{17}$ For their part, refugee-hosting states in the Global South may be seen as engaging with the regime as it serves their ends and ensures that they receive some international assistance, however modest, to respond to the mass arrival and prolonged presence of refugees on their territory. Neo-liberal perspectives, however, would argue that the scale of the challenges posed by refugee movements is beyond the capacity of any one state to resolve, resulting in the collective benefit of a regime to underpin a coordinated response. The growth of UNHCR over the past six decades also lends credence to constructivist arguments about the increasingly autonomous character of international organizations, independent from the intentions of the states that created them. Likewise, even a passing consideration of the functioning of the regime illustrates how it can very much function not as a consensus-building mechanism but as a forum of contestation, as argued by critical scholars.

In addition to highlighting the contestation implicit in relations between states and other institutional actors within the global refugee regime, critical scholarship also emphasizes the importance of including the perspectives of the subjects of interventions, and how they experience power, in our understanding of the functioning of the global refugee regime. Indeed, critical migration and citizenship scholars have demonstrated the benefits of using the perspective of refugees and migrants as an entry point to interrogate the functioning of global regimes, especially when understanding manifestations of power, resistance, and contestation in the local context. Unlike power in the global context, which tends to be expressed and experienced by states and institutions, manifestations of power in the local context have an intimate characteristic, as refugees and interveners are fused in an unequal power relationship where decisions and practices often have immediate and consequential effects on the daily lives of refugees. In these contexts, various technologies of power are employed to control the mobility, behaviour, and legal status of refugees. For example, Hyndman draws on the experience of the Dadaab refugee camps in Kenya to illustrate how coercion and disciplinary practices used by the UNHCR sought to control and produce desirable behaviour in refugees, which served a de-politicizing function. ${ }^{18}$ Despite such attempts to silence and control refugees, Nyers and Rygiel argue that spaces of control and confinement are also sites of political action where "mobilisations occur, subjectivities are formed, and contestations of the regimes governing mobility are enacted."19 Refugees make claims, judgments, and demands on the way in which global refugee policies have an impact on their individual situations. As Nyers argues, "Refugees are not supposed to be political agents ... yet everywhere they are demonstrating political agency." ${ }^{20}$ In this way, a more comprehensive understanding of the functioning of the global refugee regime must include an account of the diverse actors and forms of power present in institutional contexts at the global level, and implementation contexts at the local level.

\section{Power and Global Governance}

The need to develop more robust understandings of the functioning of power and the need to foster conversations between diverse perspectives on the various expressions and experiences of power is not limited to the study of the global refugee regime. In fact, similar challenges have been identified in understanding the role of power in the functioning of other examples of global regimes, institutions, and lawbroadly understood as the study of "global governance." ${ }^{21}$ The most prominent effort to foster such a conversation in the field of global governance is the 2005 collection edited by Barnett and Duvall, in which they consider the diverse manifestations of power in the study and practice of global governance. They argue that while power can be understood as "the production, in and through social relations, of effects that shape the capacities of actors to determine their own circumstances and fate," it is equally important to understand that "power does not have a single expression or form." 22 While different traditions within the study of international relations have sought to present an exclusive understanding of power, Barnett and Duvall argue that a taxonomy of power that incorporates various possible forms of power "detaches discussions of power from the limitations of realism, encourages scholars to see power's multiple forms, and 
discourages a presumptive dismissal of one form in favor of another." 23 In this way, the framework proposed by Barnett and Duvall is especially useful to the study of power in the global refugee regime, as it provides a context within which current understandings of power may be brought into closer conversation, while also providing a basis for future investigation not tied to a particular conceptualization of power.

Barnett and Duvall argue that there are four types of power present in global governance. The first is compulsory power. This form of power involves the exercise of direct control of one actor over another and the ability of actors "to use material resources to advance its interest in direct opposition to the interests of another." 24 While this form of power is most typically associated with the use of physical and economic power by states to compel other states to act in certain ways, they argue that some non-state actors may also exercise this type of power, even over states. Despite the role of non-interference in the international system, transnational corporations and international financial institutions have been found to exercise what amounts to compulsory power in their interactions with weaker and more marginalized states. ${ }^{25}$

This form of power has been present throughout the history of the global refugee regime. Most directly, it has been present in the ability of donor states to control the activities of UNHCR as a result of the organization's reliance on voluntary contributions. As detailed in Paragraph 20 of UNHCR's Statute, the organization would receive financial support from the un budget to cover only administrative expenses, and "all other expenditures relating to the activities of the High Commissioner shall be financed by voluntary contributions." Through this provision, "UNHCR was made financially dependent on donor governments," which "continues to be among the most significant means through which states are able to control the scope of UNHCR's work." 26 Today, this means that roughly 98 per cent of UNHCR's funding comes from voluntary contributions, primarily from a limited number of states in the Global North. Many of these states enhance the compulsory nature of their support to UNHCR by "earmarking" their contribution, thereby limiting where and how those funds may be used. For example, the United States has consistently remained the largest donor to UNHCR, typically accounting for a third of all state contributions to UNHCR, 100 per cent of which are earmarked.

Host states may also be understood to possess forms of compulsory power within the global refugee regime. Given the principle of sovereignty within the international system, and the limited enforcement mechanisms for the norms detailed in the 1951 Convention, states have ultimate control over their borders and the quantity and quality of asylum they afford to refugees. ${ }^{27}$ Since the 1980 s, the shifting interests of states in the Global South have contributed to states either restricting the number of refugees on their territory or limiting the rights of those refugees who are allowed to remain. While donors and UNHCR may seek to mitigate these responses through financial and diplomatic tools, the forced return of refugees from Bangladesh and Tanzania in the late 1990 illustrate how the restrictive policies of host states may ultimately be implemented through the use of compulsory power. This form of power is, however, frequently constrained by the imbalance of power between many host states in the Global South and donor states in the Global North, suggesting that the interaction between the forms of power presented by Barnett and Duvall needs to be more critically interrogated.

The second type of power is institutional power. This is a more diffuse form of power, primarily whereby states design international institutions to their benefit, and these institutions, in turn, come to affect the behaviour of others. This claim revolves around the understanding that more powerful states in the international system have the ability to shape the scope and mandates of new international organizations and regimes, and that these institutions then affect the behaviour of other actors. However, as argued by Hurrell and Barnett and Finnemore, ${ }^{28}$ this is arguably a less predictable form of power, as institutions may not always behave in the way intended by their founders. Indeed, Hurrell notes that traditionally weaker states in the international system are "increasingly 'rule-takers' over a whole range of issues that affect all aspects of social, economic and political life,"29 especially following their new-found majority in the United Nations General Assembly following decolonization in the 1960s.

Institutional power has also been evident throughout the history of the global refugee regime. As detailed by Loescher, ${ }^{30}$ states participating in negotiations leading to the creation of UNHCR had starkly contrasting views of the scope and functions of the new organization. Specifically, the United States "sought a temporary refugee agency with narrow authority and limited functions." In contrast, Western European states "were anxious to secure large-scale operational funds for the refugees they were supporting," while a number of non-European states, including India and Pakistan, "argued that UNHCR should be a strong, permanent organization." Ultimately, the us position prevailed, and UNHCR was established as a temporary organization with a non-political and geographically limited mandate, and a reliance on voluntary funds. Over the past sixty years, however, UNHCR has demonstrated its own ability to exercise institutional power and transform itself into a global organization with an ever-increasing mandate.

Indeed, this form of power remains central to understandings of the global refugee regime as the scope of 
UNHCR's mandate continues to evolve. For example, recent discussions on institutional responsibility for "survival migration" and "crisis migration" illustrate the enduring significance of institutional power, ${ }^{31}$ the range of actors that seek to demonstrate this form of power in the shaping and reshaping of the regime, the need to more fully understand the forms institutional power may take, and if, and how, the ability to demonstrate this form of power is contingent on other forms of power. Likewise, institutional power contributes to our understanding of the proliferation of regimes that often overlap with the global refugee regime and how states may engage in "forum-shopping" to select the regime within which "they are best able to promote specific policy preferences." 32

The third type of power, structural power, is a more diffuse form of power deriving from the "direct and mutual constitution of the capacities of actors" and the "determination of social capacities and interests." 33 While this can be understood in terms of economic capabilities and relation to the means of production, as a classical Marxist analysis would suggest, or the role of global capitalism in determining the capacities and resources of actors, as Gramscians would argue, this form of power may more generally be understood in terms of centrality or marginalization within the structure of the international system. ${ }^{34}$ In this way, the ability for a given state to act in a particular way may be conditioned or constrained by structural factors determining its place within the international system. Krasner argues that these structural factors result in a "deep asymmetry of power" between states in the Global North and Global South that "leaves almost all developing countries exposed to shocks from the international environment." 35

Structural power has arguably played both a specific and a more diffuse role in conditioning the behaviour of actors within the global refugee regime. Specifically, structural power often constrains the willingness or ability of refugeehosting states to exercise their compulsory power, as outlined above. In the case of prominent refugee-hosting states in Africa, for example, it has been argued that "it is not possible for aid-dependent states to approach the question of refugees without consideration of foreign policy implications" and that such states "do not feel free to pursue unilateral action for fear of jeopardizing relations with the donor community, upon whom they are dependent." 36 Structural inequalities also constrain the ability of many states to demonstrate institutional power. In many instances, states are constrained in their ability to individually influence the shaping and evolution of international institutions, either as a result of their position on the periphery of the international system or of the disparity in resources of different permanent missions to the United Nations in New York and Geneva. For example, when both the United States and Tanzania were members of the UN Security Council in 2006, Tanzania had 15 staff in its permanent mission in New York, while the United States had 127, in addition to roughly as many administrative support staff.

More generally, structural power helps explain the wider significance of the "North-South impasse" in the global refugee regime and points to the need to more fully engage with the political economy of the regime itself and the wider political and economic context within which the regime functions. For example, the ability of Australia to convince neighbouring small island states to support extraterritorial processing can be explained largely by the asymmetries of structural power between states in the region. ${ }^{37}$ Further research could usefully develop our understanding of the manifestations of this form of power by state and non-state actors within the regime and its implications for the functioning of the regime more generally.

The fourth type of power is productive power, defined as the "production of subjects through diffuse social relations." 38 This type of power relates to the production of subjectivities and the relationship between power and knowledge. At the core of this form of power is the ability of actors to create and enforce new realities through the use of knowledge, discourse, and claims to legitimacy. As outlined by Keeley, this form of power relates to the ability of actors to support "a dominating discourse" and "to extend or at least to defend its grasp through the conversion of others and suppression of rival knowledges." 39 More generally, this form of power relates to the ability to create and enforce categories and labels. The refugee studies literature over the past twentyfive years clearly illustrates how this is a significant form of power within the global refugee regime. ${ }^{40}$

It is here, however, that the specificity of the global refugee regime needs to be highlighted when considering the application of Barnett and Duvall's taxonomy. Unlike other areas of global governance, where the objects of categories and labels cannot resist or contest expressions of power, there is growing recognition of the fact that refugees are agents that can, and do, resist expressions of power. While some, like Bariagber, ${ }^{41}$ argue that refugees have limited ability to resist the interests of more powerful actors such as states and international organizations, others, such as Holzer, ${ }^{42}$ illustrate how refugees organize to resist and contest the imposition of policies by states and other actors. It is for this reason that understandings of power in the context of the global refugee regime need to include considerations of resistance.

Indeed, as noted by Barnett and Duvall, individuals may resist power and "seek greater capacity to influence the social forces that define them and their parameters of action." 43 Like power, there are various conceptualizations of resistance, and the form that it takes depends on the type 
of power it is confronting. For example, Barnett and Duvall argue that resistance to structural power involves actors who are in subordinate structural position attempting to reduce the inequality that is inherent in a hierarchical relationship by trying to change the structure that sustains it. Such forms of resistance are arguably found in examples of refugees staging protests and sit-ins in order to resist their subordinate structural positioning. ${ }^{44}$ In contrast, Scott argues that the resistance of those in subordinate positions can take the form of more atomized expressions, which he calls "everyday forms of resistance." 45 This includes "foot-dragging, evasion, false compliance, pilfering, feigned ignorance, slander and sabotage." 46 Although resistance can be a visible collective struggle, it can also take a more subtle form through individual creative action.

Likewise, Barnett and Duvall argue that resistance to productive power involves attempts by actors to "destabilize, even remake, their subjectivities and to transform or disrupt the broader practices through which subjectivities are produced, normalized and naturalized." 47 Resistance to productive power involves remaking or reclaiming identities. For example, Nyers utilizes the concept of "refugee warriors" to demonstrate how refugees contest the categorization of their identities as passive, victim-like, non-violent, and compliant. ${ }^{8}$ This taking of political subjectivity by the refugee subverts the binary of the speaking, visible citizen and the invisible and victim-like refugee. ${ }^{49}$

These brief considerations of resistance illustrate the wide range of actors implicated in the study of power in the global refugee regime. In recognizing that states are not the only actors to express power, and that state power may be resisted and contested by other actors such as refugees, the framework proposed by Barnett and Duvall also allows for our understanding of "the centrality of sovereignty and the powerful role of states" to be balanced with a recognition that "power is not confined to states."50 Indeed, this approach encourages an understanding that power "works and is expressed in various ways that cannot be captured by a single and simple formulation under the control of states." 51

Likewise, while the taxonomy proposed by Barnett and Duvall provides a framework through which diverse forms of power may be placed in conversation, it also highlights how power is expressed and experienced in global contexts, such as in the formal decision-making structures of the global refugee regime, and in local contexts, where efforts are made to implement those decisions. Such an approach also allows for a more nuanced understanding of the functioning of power in both the global and local manifestations of the refugee regime. For example, Betts provides a compelling account of efforts to align the interests of states in the Global North and Global South during four specific global negotiation processes: the International Conference on Assistance to Refugees in Africa (1981 and 1984); the International Conference on Central American Refugees (1987 to 1995); the Comprehensive Plan of Action for Indochinese Refugees (1988 to 1996); and the Convention Plus Initiative (2003 to 2005).52 In each case, Betts notes that UNHCR was faced with the task of "trying to persuade Northern states to voluntarily contribute to supporting refugee protection Southern states" and that it was successful in this task when it was able to "influence the beliefs of Northern states about the causal relationship between refugee protection in the South and their wider interests," especially relating to security. ${ }^{53}$ While he highlights how UNHCR's success in some of these efforts and not others "identifies the role of substantive linkages as a neglected resource for power," 54 his later study on efforts to stretch the application of the global refugee regime in six local contexts found that UNHCR was largely "epiphenomenal" in the process. 55

How can such variation in the role of UNHCR and its ability to demonstrate power be explained? Part of the answer may lie in the changing historical context of the case studies, ${ }^{56}$ although the Convention Plus initiative overlaps with the six cases Betts explored in 2013. More generally, however, this variation likely highlights the need to study the role of actors and their efforts to exert power in various contexts, both during negotiations within the global refugee regime and during efforts to implement the decisions of the regime. This points to the potential difference between the forms and functioning of power that may exist within the regime, such as in Geneva where decision-making is more formalized and access to decision-making more institutionalized, and outside the regime, in local contexts where the day-to-day implementation of decisions involves interactions across diverse contexts and a wide possibility of actors who are outside the regime. 57

\section{Understanding Power in the Global Refugee Regime}

The challenge remains to identify a process within the global refugee regime that transcends negotiations in Geneva and implementation efforts in local contexts through which the various forms of power within the global refugee regime may be observed, and for this to be recurring, thereby allowing for a consideration of the changing experience of power over time. One such opportunity may be found in the process by which global refugee policy is made and the factors that determine its implementation and non-implementation. Global refugee policy has recently been defined as a formal statement of, and proposed course of action in response to, a problem relating to protection, solutions or assistance for refugees or other populations of concern to the global refugee regime. It is discussed and approved within UNHCR's 
governing structures, such as the Executive Committee and Standing Committee, or the United Nations General Assembly, which arguably constitute the decision-making bodies of the global refugee regime. Borrowing from the work of Soroos, this policy is "global" when it takes the form of "either regulations that define the limits of permissible behavior for national governments," including through international law or ExCom Conclusions, or "as programs administered by international agencies," specifically UNHCR..$^{8}$

In recent years, considerable time and resources have been invested in efforts to develop, adopt, and implement global policies on issues as diverse as refugees in urban areas, displacement resulting from natural disasters, refugees with disabilities, and resolution of protracted refugee situations. In this way, the making and implementation of global refugee policy constitutes a core and recurring activity of the global refugee regime.

Despite the scope of these policies, there has been very limited understanding of the process through which particular issues or problems compete for prominence on the agenda of the global refugee regime's decision-making bodies, where the interests of different actors affect decisions on responses to these issues, and where a range of factors condition efforts to implement these decisions in diverse contexts. How do actors compete to raise issues on the agenda of the global refugee regime? Does the support of certain actors matter more than others? What factors condition variation in the implementation of global policies in diverse national and local contexts? How are efforts to implement global policies resisted or contested in local contexts? Are there particular forms of power that are more significant at different stages of the process? What is the consequence of competing forms of power?

These questions may serve as opportunities to consider the extent to which Barnett and Duvall's framework helps explain the behaviour of actors and their ability to demonstrate, or be affected by, power. At the same time, this framework allows for more comparability of different policy processes over time and efforts to implement the same policies in different contexts. In very simple terms, such an approach allows for a mapping of power and influence by actors at different stages in the policy process. Future studies may examine the relative exercise of power by actors in the process by which a particular policy is made at the Geneva level and the process by which it is implemented, or not implemented, in regional, national, and local contexts. ${ }^{59}$ Such an approach also highlights the contrast between the structures that condition the functioning of power at the global and local levels through a distinction between the making and implementation of policy.

Expressions of power play an important role in conditioning the "making" of global refugee policy, especially within the formal decision-making structures of the global refugee regime, such as UNHCR's Executive Committee (ExCom). As argued by Fresia, ${ }^{60}$ a limited number of state and institutional actors can exert particular influence over this process by determining which issues are placed on ExCom's agenda, in deliberating options, and in formally adopting policy. Specifically, she argues that the process of contestation and decision-making on the text of a given ExCom Conclusion not only precedes the vote by ExCom member states, but frequently occurs in sessions to which only states and UNHCR are invited and in which the power of individual state actors are especially manifest. Indeed, given the highly institutionalized nature of the making of global refugee policy, only a limited number of actors, namely states belonging to ExCom and UNHCR, participate in this process. Other actors, including NGOs and refugees, are not able to participate directly in the formal and informal process leading to decisions of UNHCR's Executive Committee.

An exception may be the role of epistemic communities, defined by Howlett and Giest as "loose groupings of experts or knowledge providers" that have the opportunity to influence the policy process by proposing "policy alternatives." ${ }^{1}$ For example, several academics were invited to contribute to the Global Consultations process, leading to the 2002 Agenda for Protection, especially through "Expert Roundtables" in 2001 on issues ranging from exclusion and cessation, nonrefoulement, and gender-related persecution, to family unity. The influence of such actors, however, may be understood as indirect at best, as their positions must be brought into the formal decision-making process either by a state or by UNHCR.

More contested, however, is the "policy implementation stage" where "global refugee policy leaves the global level and intersects with dynamics at the regional, national and local levels." 62 As global refugee policy is implemented, local dynamics intersect, influence, and shape what a policy actually achieves in practice. This is where a gap emerges between the global prescribed intent of the policy and the change it actually makes in the lives of refugees. ${ }^{63}$ In the example of urban refugees in South Africa, Landau and Amit illustrate the role of wider domestic policy spheres in creating protection gaps such as poverty alleviation, housing, public health, and development. ${ }^{64}$ Milner describes how efforts to implement a global policy on solutions for protracted refugee situations in Tanzania were constrained by changes in the domestic context of Tanzanian politics. ${ }^{65}$ Likewise, Wojnarowicz's case study of the town of GioiosaIonica, Italy, highlights how local organizations who have been outsourced to implement protection hold discretionary authority to develop new practices that contest protection and condition its provision on the acquiescence of refugees. ${ }^{66}$ As such, global refugee policy rarely reaches the local 
context uncompromised, as a wide range of policy spheres and local actors inside and outside the global refugee regime shape the outcomes for refugees and other forced migrants.

Unlike the global context of the global refugee regime where the actors, decision-making procedures, and institutions remains relatively formalized and stable, the local context is the "wild card" of implementation, varying across geographies and contexts. It is because of this high degree of local differentiation that studying micro-level dynamics remains important to unpacking how the same policy has different and often poor impacts in the lives of refugees across contexts.

The actors involved in implementation of global refugee policy consist of a multiplicity of voices that are more diverse and varied than in global institutional contexts. For their part, Betts and Orchard outline a wide range of domestic actors implicated in implementation, including formally sanctioned actors such as governments, the UNHCR, and implementing partners, but also a wide variety of nonstate actors such as INGOs, transnational civil society, and rebel groups. ${ }^{67}$ In addition, more micro-level actors such as municipalities, businesses, Mafia groups, local populations, and entire local communities can serve as gatekeepers enabling or constraining what global refugee policies do in practice. Within these actor groups the "personality, values and talents" of individuals also matter, as individuals have significant agency and discretionary authority to influence and shape how policies are practised, withstanding structural constraints. ${ }^{68}$ Crucially, although refugees are excluded from the contentions and confrontations in the creation of global refugee policy, they exert agency and make claims on the types of policies that are created in the global institutional context; how these policies are implemented by states and implementers in the local contexts; and the extent to which these policies alleviate their plight.

All four forms of power highlighted in Barnett and Duval's framework can be observed in the everyday implementation of global refugee policies. What is particular about the manifestations of power in the local context is that their forms and expressions are much more acute as refugees experience power directly in personal and intimate ways. Refugees are not mere abstract subjects but are embodied subjects who are co-constituted in intimate relationships with their surroundings. Structural and productive power are arguably the most empirically visible forms of power in the local context, as both work through "social relations of constitution." 69 Structural power works through the direct hierarchical relation of constitution, which can be observed in the refugee-implementer relationship, and productive power is concerned with the making, creating, and reaffirming of subjectivities.
Yet power is always accompanied by a certain element of resistance. Refugees assert themselves as political actors, through tactics that range from concerted action to more atomized expressions. The proliferation of dramatic acts of self-harm such as public hunger strikes and self-suturing are well documented, as well as the collective use of protest. Nyers and Moulin illustrate how Sudanese refugees in Cairo constituted themselves as a political collective and challenged UNHCR's authority and decision-making on refugee status determination decisions and resettlement procedures. ${ }^{70}$ Furthermore, Coffie describes how a six-month protest by Liberian refugees in Ghana led to intended and unintended changes in practice, such as the expansion of the timelines for repatriation, the introduction of cash allowances, and instances of refoulement..$^{71}$ In addition to grandiose acts, refugees utilize more mundane and everyday expressions of resistance such as invisibility and bypassing the refugee regime altogether, which are less dramatic but nonetheless represent a rejection of how power is experienced in their daily life.

As such, expanding our understanding of power in the global refugee regime to include the confluence of power in global and local contexts must account for the different actors involved at either scale, the most prominent forms, expressions, and experiences of power for these actors, and the strategies utilized to resist this power during the making and implementation of policy. But more than that, we must begin to trace linkages between global decision-making procedures and local implementation. How are global refugee policies experienced in the lives of refugees? How does power constrain the ability of refugees to participate in the decision-making and implementation of policies that are created to alleviate their plight? And finally, how can power be used to subvert dominant modes of operating to create new inclusive, innovative, and participatory experiences of protection and solutions to displacement?

\section{Conclusion}

The objective of this article has been to present a heuristic framework for understanding the forms of power within the global refugee regime. Drawing from the framework of power in global governance presented by Barnett and Duvall, this article has argued that at least four forms may be observed in the global refugee regime: compulsory, institutional, structural, and productive. While all four forms of power are present in the functioning of the global refugee regime, the article argues that the human-centred nature of the regime requires our analysis to consider both the expression and experience of power, and to more fully understand the ways in which expressions of power may be resisted or contested. To facilitate a more comprehensive study of 
expressions and experiences of power across contexts, the article then argued that the functioning of power and influence in the global refugee regime can usefully be observed and understood in the day-to-day practice of the regime, including in the process by which actors engage with the making and implementation of global refugee policy.

While attempting to present a heuristic framework for future research on the experience of power in the global refugee regime, and as a foundation for the articles in this special issue, this article should be understood as part of an effort to start a longer and broader conversation. Much more work is needed on the range of questions that are provoked by a deeper consideration of expressions and experiences of power across the global refugee regime. What are the foundations of power? How do expressions and experiences of power in the various contexts of the regime interact? What role do authority and legitimacy play in the perception of forms of power? Is there a hierarchy of power? And can we differentiate between the conscious and unconscious use of power? When actors use power, is it always intentional?

Given the complexity of power, its diverse manifestations, and its ability to be present in all social relations, this article does not claim to present a comprehensive or definitive treatment of power in the global refugee regime. Indeed, it makes only passing reference to the many voices that are excluded from power and marginalized from the process by which policy is made and implemented. What this article does argue, however, is that power is a more central and complex phenomenon in the study and practice of the global refugee regime than we may have previously recognized, and that a more systematic, collaborative, and inclusive conversation on power should be encouraged. Given the current state of the global refugee regime, and daily examples of its shortcomings, there is no better time to start this conversation.

\section{Notes}

1 See Aristide Zolberg, Astri Suhrke, and Sergio Aguayo, Escape from Violence: Conflict and the Refugee Crisis in the Developing World (Oxford: Oxford University Press, 1989); Gil Loescher, The UNHCR and World Politics: A Perilous Path (Oxford: Oxford University Press, 2001); Randy Lippert, "Governing Refugees: The Relevance of Governmentality to Understanding the International Refugee Regime," Alternatives: Global, Local, Political 24, no. 3 (1999): 295328; and Alexander Betts, Gil Loescher, and James Milner, UNHCR: The Politics and Practice of Refugee Protection (Abingdon, va: Routledge, 2012).

2 See, for example, Alexander Betts, Protection by Persuasion: International Cooperation in the Refugee Regime (Ithaca, NY: Cornell University Press, 2009); Betts, Loescher, and Milner, UNHCR; Jennifer Hyndman, Managing Displacement:
Refugees and the Politics of Humanitarianism (Minneapolis: University of Minnesota Press, 200o); Gil Loescher, Beyond Charity: International Cooperation and the Global Refugee Crisis (Oxford: Oxford University Press, 1993); and Zolberg, Suhrke, and Aguayo, Escape from Violence.

3 See Jennifer Hyndman and Wenona Giles, "Waiting for What? The Feminization of Asylum in Protracted Situations," Gender, Place and Culture 18, no. 3 (2011): 361-79; Susan Kneebone and Felicity Rawlings-Sanaei, eds., New Regionalism and Asylum Seekers: Challenges Ahead (Oxford: Berghahn Books, 2009); and James Milner, Refugees, the State and the Politics of Asylum in Africa (Basingstoke, UK: Palgrave Macmillan, 2009).

4 See Alexander Betts, Survival Migration: Failed Governance and the Crisis of Displacement (Ithaca, NY: Cornell University Press, 2013); Anna Lindley, ed., Crisis and Migration: Critical Perspectives (Abingdon, va: Routledge, 2014); and Susan Martin, Sanjula Weerasinghe, and Abbie Taylor, eds., Humanitarian Crises and Migration: Causes, Consequences and Responses (New York: Routledge, 2014).

5 See Hyndman, Managing Displacement; Peter Nyers, Rethinking Refugees: Beyond State of Emergency (New York: Routledge, 2006); Peter Nyers and Kim Rygiel, Citizenship, Migrant Activism and the Politics of Movement (New York: Routledge, 2012); Carolina Moulin and Peter Nyers, "We live in a country of UNHCR': Refugee Protests and Political Society, International Political Sociology 1, no. 4 (2007): 356-72; Dorothea Hilhorst and Bram J. Jansen, "Humanitarian Space as Arena: A Perspective on the Everyday Politics of Aid," Development and Change 4, no. 6 (2010): 111739; Christina Clark-Kazak, Recounting Migration: Political Narratives of Congolese Young People in Uganda (Montreal and Kingston: McGill-Queen's University Press, 2011); and Engin F. Isin and Kim Rygiel, "Abject Spaces: Frontiers, Zones, Camps," in Logics of Biopower and the War on Terror, ed. Christina Masters and Elizabeth Dauphinee, 181204 (Basingstoke, UK: Palgrave Macmillan, 2006).

6 See Jennifer Hyndman, "Mind the Gap: Bridging Feminist and Political Geography through Geopolitics," Political Geography 23 (2004): 307-22.

7 See Michael Barnett and Raymond Duvall, eds., Power in Global Governance (Cambridge: Cambridge University Press, 2005).

8 See James Milner, "Introduction: Understanding Global Refugee Policy," Journal of Refugee Studies 27, no. 4 (2014): 477-94.

9 Stephen Krasner, "Structural Causes and Regime Consequences: Regimes as Intervening Variables," in International Regimes, ed. Stephen Krasner (Ithaca, NY: Cornell University Press 1983), 2.

10 Betts, Survival Migration, 31.

11 See Betts, Protection by Persuasion, 8-13; Betts, Loescher, and Milner, UNHCR, 2012; Lippert, "Governing Refugees."

12 See John Mearsheimer, "The False Promise of International Institutions," International Security (1994): 5-49. 
13 See Kenneth Abbott and Duncan Snidal, "Why States Act through Formal International Organizations," Journal of Conflict Resolution 42, no. 1 (1998): 3-32.

14 See Robert Keohane, After Hegemony: Cooperation and Discord in the World Political Economy (Princeton: Princeton University Press, 1984).

15 See Michael Barnett and Martha Finnemore, "The Politics, Power and Pathologies of International Organizations," International Organization 53, no. 4 (1999): 699-732.

16 James Keeley, "Toward a Foucauldian Analysis of International Regimes," International Organization 44, no. 1 (1990): 84 .

17 See Martin and Ferris in this special issue.

18 Hyndman, Managing Displacement, xviii.

19 Nyers and Rygiel, Citizenship, Migrant Activism and the Politics of Movement, 8.

20 Nyers, Rethinking Refugees, xvii.

21 Mindful of his concerns with the "mushy" notion of the term, Weiss defines global governance as "the sum of the informal and formal values, norms, procedures, practices, and institutions that help states, intergovernmental organizations, civil society, and transnational corporations identify, understand and address trans-boundary problems." Thomas Weiss, Global Governance: Why? What? Whither? (Cambridge: Polity, 2013), 32.

22 Barnett and Duvall, Power in Global Governance, 3.

23 Ibid., 4.

24 Ibid., 14.

25 See Christopher Clapham, Africa and the International System: The Politics of State Survival (Cambridge: Cambridge University Press, 1996); and Robert Jackson, Quasi-States: Sovereignty, International Relations and the Third World (Cambridge: Cambridge University Press, 1990).

26 Betts, Loescher, and Milner, UNHCR, 15.

27 See Milner, Refugees, the State and the Politics of Asylum in Africa.

28 Andrew Hurrell, "Power, Institutions, and the Production of Inequality," in Barnett and Duvall, Power in Global Governance, 33-58; Michael Barnett and Martha Finnemore, "The Power of Liberal International Organizations," in Barnett and Duvall, Power in Global Governance, 161-84.

29 Hurrell, "Power, Institutions, and the Production of Inequality," 49.

30 Loescher, UNHCR and World Politics, 43-4.

31 See Betts, Survival Migration; Martin, Weerasinghe, and Taylor, Humanitarian Crises and Migration.

32 Alexander Betts, “The Refugee Regime Complex," Refugee Survey Quarterly 29, no. 4 (2010): 13.

33 Barnett and Duval, Power in Global Governance, 18.

34 See Clapham, Africa and the International System; Jackson, Quasi-States.

35 Stephen Krasner, Structural Conflict: The Third World against Global Liberalism (Berkeley: University of California Press, 1985), 294.
36 Milner, Refugees, the State and the Politics of Asylum in Africa, 181-2.

37 Susan Kneebone, "The Bali Process and Global Refugee Policy in the Asia-Pacific Region," Journal of Refugee Studies 27, no. 4 (2014): 596-618.

38 Barnett and Duvall, Power in Global Governance, 20.

39 Keeley, "Toward a Foucauldian Analysis of International Regimes," 99.

40 See Nyers, Rethinking Refugees; Roger Zetter, "Labelling Refugees: Forming and Transforming a Bureaucratic Identity," Journal of Refugee Studies 4, no. 1 (1991): 39-62; Lippert, "Governing Refugees."

41 Assefaw Bariagaber, "States, International Organizations and the Refugee: Reflections on the Complexity of Managing Refugee Crisis in the Horn of Africa," Journal of Modern African Studies 37, no. 4 (1999): 597-619.

42 Elizabeth Holzer, The Concerned Women of Buduburam: Refugee Activists and Humanitarian Dilemmas (Ithaca, NY: Cornell University Press, 2015).

43 Barnett and Duvall, Power in Global Governance, 22.

44 See Moulin and Nyers, "We live in a country of UnHCR."

45 James C. Scott, Weapons of the Weak: Everyday Forms of Peasant Resistance (New Haven, Cт: Yale University Press, 1987).

46 Scott, Weapons of the Weak, 27.

47 Barnett and Duvall, Power in Global Governance, 23.

48 Nyers, Rethinking Refugees.

49 See Nyers cited in Alexandra Hall, Border Watch: Cultures of Immigration Detention and Control (New York: Pluto, 2012), 111.

50 Weiss, Global Governance, 36.

51 Ibid., 37.

52 Betts, Protection by Persuasion.

53 Ibid., 3-4.

54 Ibid., 4.

55 Betts, Survival Migration, 50.

56 See Astri Suhrke, "Burden-Sharing during Refugee Emergencies: The Logic of Collective versus National Action," Journal of Refugee Studies 11, no. 4 (1998): 396-415.

57 This distinction parallels recent debates on norm implementation and studying the "everyday politics" of international actors in local contexts. See Alexander Betts and Phil Orchard, eds., Implementation and World Politics: How International Norms Change Practice (Oxford: Oxford University Press, 2014); and Séverine Autesserre, Peaceland: Conflict Resolution and the Everyday Politics of International Intervention (Cambridge: Cambridge University Press, 2014).

58 Milner, "Introduction," 480.

59 Marion Fresia, "Building Consensus within UNHCR's Executive Committee: Global Refugee Norms in the Making," Journal of Refugee Studies 27, no. 4 (2014): 514-33; and James Milner, "Can Global Refugee Policy Leverage Durable Solutions? Lessons from Tanzania's Naturalization of 
Burundian Refugees," Journal of Refugee Studies 27, no. 4 (2014): 553-73.

60 Fresia, "Building Consensus."

61 M. Howlett and S. Giest, "The Policy-Making Process," in Routledge Handbook of Public Policy, ed. E. Araral Jr., S. Fritzen, M. Howlett, M. Ramesh, and X. Wu (Abingdon, VA: Routledge, 2013), 19.

62 Milner, "Introduction.

63 See ibid.

64 Loren B. Landau and Roni Amit, "Wither Policy? Southern African Perspectives on Understanding Law, 'Refugee' Policy and Protection," Journal of Refugee Studies 27, no. 4 (2014): 534-52.

65 See Milner, Refugees, the State and the Politics of Asylum in Africa.

66 Krystyna Wojnarowicz, "Power and the 'Everyday Politics' of Refuge Protection in the Case Study of Gioiosa-Ionica, Italy" (MA thesis, Carleton University, 2016).
67 Betts and Orchard, Implementation and World Politics. t68 Ibid., 284.

69 Barnett and Duvall, Power in Global Governance, 12. 70 See Moulin and Nyers, "We live in a country of UNHCR."

71 Amanda Coffiie, "Rethinking to Rebuild: Forced Migration, Resource Transformation and Reintegration of Liberian Returnees from Ghana and Guinea" (PhD diss., Carleton University, 2013).

James Milner is associate professor of political science at Carleton University, Ottawa. The author may be contacted at james.milner@carleton.ca.

Krystyna Wojnarowicz has an MA in political science from Carleton University. The author may be contacted at krystyna.wojnarowicz@carleton.ca. 